\title{
Korelasi Nilai APGAR Menit Kelima Kurang dari Tujuh dengan Kadar Transaminase Serum pada Bayi Baru Lahir
}

\author{
Ali K Alhadar, Idham Amir, Hanifah Oswari, Endang Windiastuti \\ Departemen Ilmu Kesehatan Anak, Fakultas Kedokteran Universitas Indonesia, Rumah Sakit Dr. Cipto \\ Mangunkusumo
}

Latar belakang. Asfiksia dapat menyebabkan disfungsi multiorgan pada bayi baru lahir. Belum ada baku emas mengenai definisi asfiksia. Hingga saat ini belum ada data di FKUI/RSCM mengenai insidens disfungsi hati pada bayi yang mengalami asfiksia.

Tujuan. Mengetahui insidens disfungsi hati pada bayi baru lahir dengan nilai Apgar menit kelima kurang dari 7 serta mengetahui korelasi antara nilai Apgar menit kelima kurang dari 7 dengan parameter uji fungsi hati (AST/SGOT, ALT/SGPT, bilirubin total, bilirubin direk, bilirubin indirek serta waktu protrombin). Penelitian dilakukan di 5 rumah sakit di Jakarta dan Tangerang.

Metode. Studi analitik potong lintang sejak Januari-Mei 2010. Subjek penelitian adalah bayi usia gestasi $\geq 37$ minggu dengan nilai Apgar menit kelima kurang dari 7. Dilakukan satu kali pemeriksaan uji fungsi hati dalam rentang waktu usia bayi 24-96 jam. Bayi mengalami disfungsi hati bila didapatkan nilai AST atau ALT lebih dari $100 \mathrm{U} / \mathrm{L}$.

Hasil. Disfungsi hati ditemukan pada $16(34 \%)$ bayi dari 47 bayi dengan asfiksia. Tidak ada subjek yang mengalami kolestasis. Terdapat 5 (11\%) subjek dengan pemanjangan PT >1,5 kali nilai kontrol. Tidak terbukti terdapat korelasi antara nilai Apgar menit kelima kurang dari 7 dengan parameter uji fungsi hati.

Kesimpulan. Bayi dengan nilai Apgar menit kelima kurang dari 7 mempunyai kecenderungan mengalami disfungsi hati. Namun pada bayi dengan nilai Apgar menit kelima kurang dari 7, tidak terbukti adanya korelasi. Sari Pediatri 2010;12(3):190-6.

Kata kunci: asfiksia, AST, ALT, disfungsi hati

\section{1 sfiksia neonatal merupakan masalah global yang berperan dalam meningkatkan angka morbiditas dan mortalitas. Insidens asfiksia di negara maju 1,1-2,4 kasus per 1000}

\section{Alamat korespondensi:}

Dr. Idham Amir, Sp.A(K). Divisi Perinatologi. Departemen Ilmu Kesehatan Anak FKUI RSCM. Jl. Salemba no. 6. Jakarta 10430. Telp. 021-3154020 kelahiran hidup. ${ }^{1}$ Insidens dan prevalens asfiksia di negara berkembang kemungkinan lebih tinggi akibat keterbatasan fasilitas pelayanan reproduksi dan sumber daya manusia.

Untuk kepentingan klinis, asfiksia dapat didefinisikan sebagai suatu keadaan terganggunya pertukaran gas yang menyebabkan hipoksemia, hiperkapnia dengan asidosis metabolik yang bermakna. ${ }^{2}$ Baku emas untuk definisi birth asphyxia belum ada. ${ }^{3}$ American 
Academy of Pediatrics (AAP) dan American College of Obstetrician and Gynecologyst (ACOG) menetapkan empat kriteria yang harus ada dalam mendefinisikan asfiksia, yaitu: asidosis metabolik atau asidosis campuran dengan $\mathrm{pH}<7,00$ pada arteri umbilikalis, nilai Apgar 0-3 pada menit kelima atau lebih, manifestasi neurologi segera pada periode perinatal (termasuk kejang, hipotonus, koma atau ensefalopati hipoksiaiskemia), serta ada bukti disfungsi multiorgan pada periode neonatal. ${ }^{4,5}$ The National Neonatal Perinatal Database (NNPD) ${ }^{3}$ di India dan kesepakatan di Divisi Perinatologi Departemen Ilmu Kesehatan Anak Fakultas Kedokteran Universitas Indonesia Rumah Sakit Dr. Cipto Mangunkusumo menggunakan nilai Apgar 4-6 pada menit pertama sebagai asfiksia sedang dan nilai Apgar 0-3 pada menit pertama sebagai asfiksia berat.

Asfiksia menyebabkan ensefalopati hipoksikiskemik serta disfungsi multiorgan lain seperti ginjal, sistem pernapasan, jantung, hati, saluran cerna, dan sistem hematologi. ${ }^{6-9}$ Disfungsi multiorgan ini akan berpengaruh terhadap prognosis selama perawatan. Beberapa penelitian terdahulu telah dilakukan untuk melihat disfungsi multiorgan pada bayi dengan asfiksia. Epidemiologi disfungsi organ pada asfiksia tertera pada Tabel 1.

Asfiksia akan menyebabkan redistribusi aliran darah (refleks diving) ke otak, jantung dan kelenjar adrenal, sehingga aliran darah ke organ lain akan berkurang selain itu terjadi metabolisme anaerob yang menyebabkan keadaan asidosis. Mekanisme refleks diving dan asidosis akan menyebabkan kerusakan sel hati yang dapat menyebabkan disfungsi hati.

Pemeriksaan laboratorium fungsi hati dibagi dalam empat kelompok yaitu pemeriksaan marker integritas hepatosit (AST/SGOT dan ALT/SGPT), produk biosintesis hepatosit (waktu protrombin dan albumin), produk metabolisme hepatosit (bilirubin) dan indikator kolestasis (fosfatase alkali dan serum gamma-glutamiltransferase). ${ }^{10}$ Manifestasi klinis dan laboratorium yang dapat terjadi pada disfungsi hati adalah ikterus, perubahan warna tinja, perdarahan, peningkatan enzim hepatoseluler dan bilier, pemanjangan waktu protrombin, penurunan kadar antitrombin III, protein $C$ dan protein $S$ serta penurunan fungsi defensif hati yang memudahkan terjadinya sepsis di kemudian hari. ${ }^{11}$

Keterlibatan organ hati pada asfiksia neonatal merupakan hal yang telah diketahui, namun biasanya tidak dianggap sebagai bagian dari disfungsi multiorgan pada asfiksia neonatal. ${ }^{12,13}$ Hingga saat ini belum banyak penelitian mengenai disfungsi hati pada asfiksia neonatal di dunia. Data yang sama di FKUI/ RSCM juga belum tersedia. Pemeriksaan fungsi hati pada bayi asfiksia di Divisi Perinatologi FKUI/RSCM belum dilakukan secara rutin. Tujuan studi ini adalah untuk mengetahui insidens disfungsi hati dan korelasi antara nilai Apgar menit kelima kurang dari 7 dengan parameter uji fungsi hati.

\section{Metode}

Studi analitik potong lintang, dilakukan secara prospektif selama 5 bulan (1 Januari - 31 Mei 2010) di lima rumah sakit, dengan pengumpulan sampel secara konsekutif. Tempat penelitian tersebut adalah Divisi Perinatologi Departemen Ilmu Kesehatan Anak FKUI/RSCM, RS Pusat Angkatan Darat (RSPAD), RS Ibu dan Anak Budi Kemuliaan (RSIABK), RS Budi Asih (RSBA), dan RS Sari Asih Tangerang (RSSA).

Tabel 1. Epidemiologi disfungsi multiorgan pada asfiksia

\begin{tabular}{lcccc}
\hline \multicolumn{1}{c}{$\begin{array}{c}\text { Sistim } \\
\text { organ }\end{array}$} & $\begin{array}{c}\text { Ancel (1995) } \\
\mathrm{N}=72\end{array}$ & $\begin{array}{c}\text { Shah (2004) } \\
\mathrm{N}=130\end{array}$ & $\begin{array}{c}\text { Hankins 2002) } \\
\mathrm{N}=46\end{array}$ & $\begin{array}{c}\text { Korst 1999) } \\
\mathrm{N}=47\end{array}$ \\
\hline Susunan saraf pusat & $72 \%$ & $100 \%$ & $70 \%$ & $96 \%$ \\
Ginjal & $42 \%$ & $70 \%$ & $72 \%$ & $17 \%$ \\
Paru & $26 \%$ & $86 \%$ & - & $55 \%$ \\
Hati & - & $85 \%$ & $80 \%$ & $23 \%$ \\
Saluran cerna & $29 \%$ & - & - & - \\
Hematologi & - & - & $54 \%$ & $23 \%$ \\
Jantung & - & $60 \%$ & $78,2 \%$ & $26 \%$ \\
\hline
\end{tabular}

Sari Pediatri, Vol. 12, No. 3, Oktober 2010 
Ali K Alhadar dkk: Korelasi nilai APGAR menit kelima dengan kadar transaminase serum pada bayi baru lahir

Kriteria inklusi adalah bayi baru lahir dengan usia gestasi $\geq 37$ minggu dengan nilai Apgar menit kelima kurang dari 7. Kriteria eksklusi adalah bayi dengan kelainan kongenital mayor, terbukti infeksi TORCH dan inborn error metabolism. Asfiksia bila didapatkan nilai Apgar menit kelima kurang dari 7. Pemeriksaan uji fungsi hati dilakukan satu kali dalam rentang waktu usia bayi 24-96 jam. Bayi mengalami disfungsi hati bila nilai AST atau ALT lebih dari $100 \mathrm{U} / \mathrm{L}$.

Besar sampel dihitung dengan formula estimasi proporsi populasi tunggal dengan angka ketepatan $5 \%$ dan prevalens disfungsi hati pada bayi asfiksia sebesar $80 \%{ }^{7}$ sehingga diperoleh sampel minimal 62 subjek. Besar sampel untuk korelasi nilai Apgar dengan parameter uji fungsi hati digunakan formula koefisien korelasi sampel tunggal dengan besar nilai $\mathrm{r}=0,47,{ }^{14}$ tingkat kemaknaan 0,05 , dan power $80 \%$, diperoleh besar sampel 34 subjek.

Data diolah dengan perangkat piranti lunak SPSS 17 dengan uji statistik korelasi Spearman dan disajikan secara deskriptif dan tabular. Persetujuan etik diperoleh dari Komite Etik Fakultas Kedokteran Universitas Indonesia.

\section{Hasil}

Selama kurun waktu lima bulan didapatkan 47 subjek dengan nilai Apgar menit kelima kurang dari 7. Median usia gestasi subjek adalah 39 minggu (3743 minggu) dengan rerata berat lahir 2924 (SB 505) gram dan rerata panjang lahir $48(\mathrm{SB} 2) \mathrm{cm}$. Biakan darah tidak dilakukan pada 4 subjek, dengan alasan tidak dicurigai sebagai sepsis pada 2 subjek dan tidak ada biaya pada dua subjek lainnya. Didapatkan hasil biakan darah positif pada 7 subjek. Hasil biakan darah tersebut adalah Staphylococcus epidermidis pada 4 subjek, Klebsiella pneumonia pada 3 subjek, dan Seratia liquiefaciens pada satu subjek. Didapatkan 2 subjek yang mengalami disfungsi hati dengan hasil kultur darah positif. Karakteristik subjek penelitian tertera pada Tabel 2.

Pada bayi dengan nilai Apgar menit kelima kurang dari 7 didapatkan rerata (simpang baku) kadar AST $92(54,1)$ U/L dan rentang nilai AST adalah 28286 U/L. Rerata kadar ALT 53 (74,1) U/L dengan rentang nilai ALT adalah 3-436 U/L. Berdasarkan kriteria disfungsi hati (AST atau ALT $>100 \mathrm{U} / \mathrm{L}$ ) maka didapatkan 16 dari 47 (34\%) subjek yang
Tabel 2. Karakteristik subjek penelitian $(n=47)$

\begin{tabular}{lcc}
\hline Karakteristik & $\mathrm{n}$ & $\%$ \\
\hline Jenis kelamin & & \\
$\quad$ Lelaki & 28 & 60 \\
$\quad$ Perempuan & 19 & 40 \\
Usia gestasi & & \\
$\quad$ Cukup bulan & 41 & 87 \\
$\quad$ Lebih bulan & 6 & 13 \\
Berat lahir (gram) & & \\
$\quad<2500$ & 9 & 19 \\
$\quad 22500$ & 38 & 81 \\
Nilai Apgar menit & & \\
kelima & & \\
1-3 & 2 & 4 \\
4-6 & 45 & 96 \\
Cara persalinan & & \\
$\quad$ Spontan & 15 & 32 \\
Ekstraksi vakum & 11 & 23 \\
$\quad$ Ekstraksi forseps & 3 & 6 \\
$\quad$ Bedah kaisar & 18 & 39 \\
Kultur darah & & \\
$\quad$ Ditemukan bakteri & 7 & 15 \\
Steril & 36 & 77 \\
$\quad$ Tidak dilakukan & 4 & 8 \\
\hline
\end{tabular}

Tabel 3. Hasil uji fungsi hati pada bayi dengan nilai Apgar menit kelima kurang dari 7

\begin{tabular}{lcc}
\hline Variabel & $\begin{array}{c}\text { Apgar 1-3 } \\
\mathrm{n}=2\end{array}$ & $\begin{array}{c}\text { Apgar 4-6 } \\
\mathrm{n}=45\end{array}$ \\
\hline Peningkatan AST (U/L) n (\%) & & \\
$\quad$ Normal (0-100) & $0(0)$ & $31(69)$ \\
Ringan (100-200) & $2(100)$ & $12(27)$ \\
Sedang (200-1000) & $0(0)$ & $2(4)$ \\
Berat (>1000) & $0(0)$ & $0(0)$ \\
Peningkatan ALT (U/L) n (\%) & & \\
Normal & $1(50)$ & $40(89)$ \\
Ringan (100-200) & $1(50)$ & $4(9)$ \\
Sedang (200-1000) & $0(0)$ & $1(2)$ \\
Berat (>1000) & $0(0)$ & $0(0)$ \\
Bilirubin direk (mg/dL) n (\%) & & \\
Normal & $0(0)$ & $47(100)$ \\
Kolestasis & $0(0)$ & $0(0)$ \\
Waktu protrombin n (\%) & & \\
Normal & $0(0)$ & $23(51)$ \\
Memanjang 1,5x kontrol & $0(0)$ & $5(11)$ \\
\hline
\end{tabular}


Tabel 4. Korelasi nilai Apgar menit kelima kurang dari 7 dengan parameter uji fungsi hati pada bayi baru lahir.

\begin{tabular}{lcc}
\hline Variabel & $r$ & $p^{\#}$ \\
\hline AST & $-0,006$ & 0,970 \\
ALT & $-0,044$ & 0,767 \\
Bilirubin total & $-0,058$ & 0,700 \\
Bilirubin direk & 0,102 & 0,497 \\
Bilirubin indirek & $-0,069$ & 0,645 \\
PT & 0,103 & 0,490 \\
\hline
\end{tabular}

\#uji Spearman, $p>0,05$
Hasil PT yang abnormal atau memanjang lebih dari dua detik dibandingkan nilai kontrol pada 24 (51\%) bayi. Rerata pemanjangan PT 5,3 (SB 4,3) detik, rentang nilai pemanjangan 2,1-20,2 detik. Jumlah subjek yang mengalami pemanjangan PT lebih dari 1,5 kali nilai kontrol didapatkan pada 5 (11\%) bayi.

Berdasarkan uji korelasi Spearman pada parameter uji fungsi hati, tidak terbukti ada korelasi antara nilai Apgar menit kelima kurang dari 7 dengan parameter uji fungsi hati, karena nilai $p$ yang tidak bermakna secara statistik. (Tabel 4).

Tabel 5. Kriteria penelitian lain dengan insidens disfungsi hati yang lebih besar dibandingkan penelitian ini

\begin{tabular}{lcccc}
\hline Kriteria & $\begin{array}{c}\text { Penelitian ini } \\
\mathrm{n}=47\end{array}$ & $\begin{array}{c}\text { Godambe }(1997) \\
\mathrm{n}=70\end{array}$ & $\begin{array}{c}\text { Shah (2004) } \\
\mathrm{n}=130\end{array}$ & $\begin{array}{c}\text { Hankins (2002) } \\
\mathrm{n}=46\end{array}$ \\
\hline $\begin{array}{l}\text { Apgar } \\
\text { Ensefalopati }\end{array}$ & Menit kelima $<7$ & Menit pertama $\leq 7$ & $85 \%$ & $80 \%$ \\
AST atau ALT & AST atau ALT $>100$ & ALT $>40 \mathrm{U} / \mathrm{L}$ & $\begin{array}{c}\text { Menit kelima }<5, \\
\text { Ensefalopati }(+)\end{array}$ & Ensefalopati (+) \\
& U/L & & AST atau ALT & AST atau ALT: \\
& & & $>100 \mathrm{U} / \mathrm{L}$ & 1,5 kali normal \\
Usia gestasi & $\geq 37$ minggu & Prematur $(+)$ & Cukup bulan & $\geq 32$ minggu \\
\hline
\end{tabular}

Tabel 6. Kriteria penelitian lain dengan insidens disfungsi hati yang hampir sama dan lebih sedikit dibandingkan penelitian ini

\begin{tabular}{|c|c|c|c|}
\hline Kriteria & $\begin{array}{c}\text { Penelitian ini } \\
\mathrm{n}=47\end{array}$ & $\begin{array}{c}\text { Korst (1999) } \\
\mathrm{n}=47\end{array}$ & $\begin{array}{c}\text { Tarcan }(2007) \\
\mathrm{n}=56\end{array}$ \\
\hline & $34 \%$ & $23 \%$ & $39 \%$ \\
\hline $\begin{array}{l}\text { Apgar } \\
\text { Ensefalopati }\end{array}$ & Menit kelima $<7$ & $\begin{array}{l}\text { Penelitian retrospektif, } \\
\text { riwayat ensefalopati }(+) \text { dan } \\
\text { bukti sequele neurologis di } \\
\text { kemudian hari }\end{array}$ & $\begin{array}{c}\text { AS menit kelima }<5 \\
\text { Ensefalopati }(+)\end{array}$ \\
\hline AST atau ALT & AST atau ALT $>100 \mathrm{U} / \mathrm{L}$ & AST atau ALT > $100 \mathrm{U} / \mathrm{L}$ & ALT > $100 \mathrm{U} / \mathrm{L}$ \\
\hline Usia gestasi & $\geq 37$ minggu & Cukup bulan & Prematur $>30$ minggu \\
\hline
\end{tabular}

mengalami disfungsi hati (Tabel 3). Peningkatan AST $>100 \mathrm{U} / \mathrm{L}$ tanpa disertai peningkatan ALT $>100 \mathrm{U} / \mathrm{L}$ didapatkan pada $10(21 \%)$ subjek. Semua subjek yang mengalami peningkatan ALT juga didapatkan peningkatan AST.

Tidak ada subjek yang mengalami ikterus pada usia kurang dari 24 jam dan kolestasis. Rentang kadar bilirubin total $0,87-15,74 \mathrm{mg} / \mathrm{dL}$, rentang kadar bilirubin indirek adalah $0,47-15,19 \mathrm{mg} / \mathrm{dL}$ dan rentang kadar bilirubin direk adalah $0,2-2,1 \mathrm{mg} / \mathrm{dL}$. Rentang waktu protrombin 10,5-32,2 detik. Rerata waktu protrombin 14,8 $(3,8)$ detik. Rerata nilai kontrol 11,8 (SB 0,4) detik, dengan rentang nilai 10,9-12,9 detik.

\section{Pembahasan}

Pada penelitian ini terdapat beberapa keterbatasan. Penelitian mengenai asfiksia pada umumnya menggunakan kriteria asfiksia yang diajukan oleh AAP-ACOG. ${ }^{6,15}$ Penelitian ini hanya menggunakan kriteria asfiksia berdasarkan nilai Apgar menit kelima kurang dari 7. Infeksi hepatitis B pada neonatus dapat menyebabkan terjadinya disfungsi hati, namun pada studi ini tidak semua subjek penelitian dilakukan pemeriksaan uji tapis hepatitis B pada orangtua. Pemeriksaan laboratorium lain untuk menyingkirkan penyakit metabolik, herpes simpleks, hemokromatosis neonatal, leukemia kongenital 
dan hepatitis autoimun juga tidak dilakukan pada subjek maupun orangtua subjek.

Keadaan sepsis dapat menyebabkan disfungsi hati, pada penelitian ini ditemukan 2 subjek yang mengalami disfungsi hati dengan hasil kultur darah positif. Kondisi sepsis menjadi salah satu faktor perancu dengan keadaan asfiksia. Parameter uji fungsi hati yang cenderung lebih sering meningkat pada keadaan sepsis adalah kadar bilirubin direk dibandingkan dengan enzim transaminase. Pada penelitian ini subjek yang terbukti sepsis tidak dikeluarkan dari analisis sebab sepsis juga merupakan salah satu faktor risiko terjadinya asfiksia.

Penilaian nilai Apgar pada penelitian kami tidak dilakukan oleh satu orang sehingga dapat terjadi perbedaan penentuan penilaian nilai Apgar antara setiap penolong persalinan (inter-observer variation). Pemeriksaan uji fungsi hati pada setiap subjek tidak dilakukan pada satu waktu namun dilakukan pada rentang waktu antara 24-96 jam sehingga kemungkinan besar telah terjadi perubahan-perubahan pada parameter tersebut sehingga tidak dapat diambil kesimpulan yang tepat. Pemeriksaan uji fungsi hati tidak dilakukan pada satu laboratorium sehingga terdapat kemungkinan perbedaan nilai hasil uji fungsi hati.

\section{Insidens disfungsi hati}

Enzim ALT merupakan marker kerusakan sel hati yang spesifik karena ALT hanya terdapat di hati, sedangkan AST terdapat juga pada organ lain seperti jantung, otot, ginjal, otak, pankreas, dan sel darah merah. ${ }^{16}$ Penelitian oleh Hankins, ${ }^{7}$ Karlsson ${ }^{14}$ dan Shah ${ }^{15}$ menggunakan kriteria AST dan ALT sebagai kriteria disfungsi hati. Penelitian oleh Tarcan ${ }^{12}$ dan Godambe ${ }^{17}$ hanya menggunakan ALT sebagai kriteria disfungsi hati.

Persentase insidens disfungsi hati pada penelitian kami (34\%) lebih kecil dibandingkan hasil yang didapatkan oleh peneliti-peneliti lain sebesar 85\%, $80 \%$, dan $75 \%$ yang dilakukan di Amerika, Kanada dan India. ${ }^{7,15,17}$ Hasil penelitian kami hampir sama dengan penelitian yang dilakukan oleh Tarcan ${ }^{12}$ di Turki 39\%. Penelitian lain oleh Korst di Amerika mendapatkan angka disfungsi hati pada bayi asfiksia lebih rendah $(23 \%)^{6}$

Penelitian prospektif oleh Hankins ${ }^{7}$ di Amerika selama 6 tahun pada bayi dengan usia gestasi $\geq 32$ minggu yang mengalami asfiksia dan ensefalopati mendapatkan angka insidens disfungsi hati 80\% (37 dari 46 subjek). Penelitian Hankins menggunakan kriteria disfungsi hati dengan nilai AST atau ALT > 75 U/L. Penelitian Godambe ${ }^{17}$ di India pada bayi prematur dan cukup bulan menggunakan kriteria asfiksia dengan nilai Apgar menit pertama $\leq 7$. Kriteria disfungsi hati yang digunakan adalah peningkatan ALT lebih dari 40 U/L. Nilai titik potong peningkatan ALT yang digunakan Hankins dan Godambe pada penelitiannya lebih rendah dibandingkan dengan studi ini.

Penelitian Shah ${ }^{15}$ pada bayi cukup bulan dengan kriteria asfiksia nilai Apgar menit kelima kurang dari 5, asidosis metabolik, dan HIE mendapatkan insidens disfungsi hati sebesar 85\% (110 dari 130 subjek). Kriteria disfungsi hati yang digunakan pada penelitian Shah ini adalah peningkatan AST atau ALT > 100 U/L. Dibandingkan dengan penelitian kami, kriteria asfiksia dan nilai titik potong pada ketiga penelitian tersebut menyebabkan terdapatnya perbedaan insidens disfungsi hati. Kriteria yang digunakan pada beberapa studi di atas memberikan hasil prevalens disfungsi hati yang ditemukan juga menjadi lebih besar., ${ }^{74,15,17}$ Perbedaan tersebut tertera pada Tabel 5. Alasan lain mengenai perbedaan hasil disfungsi hati yang didapatkan pada berbagai studi sebelumnya mungkin dapat dijelaskan oleh perbedaan waktu pengambilan sampel darah. ${ }^{15}$

Penelitian oleh Korst $^{6}$ mendapatkan angka yang rendah $23 \%$, hal ini mungkin disebabkan desain penelitian retrospektif dengan kriteria inklusi mengharuskan pasien memiliki riwayat HIE dan adanya bukti gejala sisa (sequele) neurologis pada pemantauan jangka panjang, sehingga kemungkinan pasien yang tidak mengalami gejala sisa neurologis namun sebenarnya mengalami hipoksia pada saat lahir tidak termasuk dalam subjek penelitian.

Penelitian oleh Tarcan pada bayi cukup bulan menggunakan kriteria yang lebih ketat namun hasilnya hampir sama dibandingkan studi ini. Perbedaan hasil penelitian Tarcan ${ }^{12}$ dengan penelitian Shah, ${ }^{15}$ Hankins, ${ }^{7}$ dan Karlsson ${ }^{14}$ disebabkan karena peningkatan enzim transaminase akibat hipoksia pada neonatus mungkin tidak sebesar pada pasien dewasa atau anak. Keadaan hipoksia akut pada neonatus tidak mengakibatkan efek yang berat, karena hati memang relatif lebih hipoksia pada periode antenatal karena fisiologi aliran darah hati $\left(\mathrm{pO}_{2}=30-35 \mathrm{mmHg}\right){ }^{18}$ Perbandingan kriteria yang menunjukkan mengapa terdapat insidens disfungsi hati yang hampir sama atau lebih sedikit dibandingkan dengan studi ini tertera pada Tabel 6 . 
Hanya terdapat satu kepustakaan yang meneliti mengenai hubungan parameter uji fungsi hati terhadap derajat HIE yang dilakukan oleh Karlsson. ${ }^{14}$ Studi tersebut menunjukkan korelasi yang lemah antara peningkatan AST $(r=0,41)$ dan ALT $(r=0,47)$ dengan derajat HIE pada usia 1 hari serta AST $(r=0,48)$ dan ALT $(r=0,53)$ pada usia 2 hari. Sedangkan pada usia 3 hari, terdapat korelasi kuat antara AST $(r=0,81)$ dan ALT $(r=0,81)$ dengan derajat HIE.

Hubungan nilai Apgar menit kelima kurang dari 7 dengan kadar bilirubin total, bilirubin direk, bilirubin indirek

Pada bayi cukup bulan 40\%-60\% mengalami hiperbilirubinemia fisiologis, dengan peningkatan bilirubin indirek. Parameter bilirubin total dan bilirubin indirek tidak dapat dijadikan acuan sebagai bukti adanya disfungsi hati. Bila didapatkan peningkatan bilirubin direk pada neonatus hal ini merupakan keadaan patologis. Mekanisme sekresi bilirubin pada sel hati memerlukan energi dan pada keadaan hipoksia-iskemia mekanisme sekresi empedu dapat terganggu sehingga memudahkan terjadinya kolestasis. Selain itu kolestasis juga dapat terjadi akibat kerusakan pada sel kanalikulus atau duktus biliaris pada waktu hipoksemi-iskemia terjadi. ${ }^{19,20}$ Penelitian yang dilakukan oleh Tiker dkk. ${ }^{20}$ dan Jacquemin ${ }^{19}$ menemukan bayi-bayi dengan diagnosis transient cholestasis memiliki riwayat asfiksia saat lahir tanpa adanya penyakit lain.

\section{Hubungan nilai Apgar menit kelima kurang dari 7 dengan nilai PT}

Pembekuan merupakan hasil akhir dari proses reaksi protein-protein koagulasi. Hati merupakan organ utama pembentuk protein koagulasi. Pemeriksaan PT mengukur waktu yang diperlukan untuk mengubah protrombin menjadi trombin yang memerlukan faktor I, II, V, VII dan X, yang mencerminkan faktor pembekuan jalur ekstrinsik yang dibentuk oleh hati. Pemanjangan nilai PT terjadi bila ada defisiensi faktor pembekuan tersebut. Pemanjangan PT tidak hanya disebabkan oleh disfungsi hati, dapat juga terjadi pada keadaan defisiensi vitamin-K dan disseminated intravascular coagulation (DIC) akibat sepsis, oleh sebab itu perlu berhati-hati dalam menginterpretasi hasil PT. ${ }^{12,21}$ Nilai PT yang memanjang pada neonatus yang telah mendapatkan vitamin K dapat menggambarkan adanya disfungsi hati. ${ }^{10}$ Nilai PT dianggap abnormal bila memanjang lebih dari 2 detik dibandingkan kontrol. ${ }^{21,22}$ Batres mengatakan risiko perdarahan lebih mudah terjadi pada nilai PT yang memanjang lebih dari 3 detik dibandingkan nilai kontrol. ${ }^{23}$ Kesepakatan di Departemen IKA FKUI mengenai pemanjangan PT yang memerlukan terapi plasma beku (FFP) adalah bila PT memanjang lebih dari 1,5 kali nilai normal.

Penelitian yang dilakukan Beshlawy ${ }^{24}$ pada 10 bayi dengan asfiksia dan HIE didapatkan rerata PT 17,6 (SB 3,1) detik dan semua pasien (100\% bayi) mengalami pemanjangan PT. Studi lain yang dilakukan oleh Karlsson $\mathrm{dkk}^{14}$ pada subjek asfiksia didapatkan peningkatan international normalized ratio (INR) yang bermakna pada usia 1 dan 2 hari.

\section{Manfaat pemeriksaan parameter uji fungsi hati pada bayi asfiksia}

Pemeriksaan uji fungsi hati (AST, ALT, bilirubin total, bilirubin direk, bilirubin indirek serta PT) dibandingkan dengan pemeriksaan fungsi organ lain (seperti jantung, paru, saluran cerna, dan hematologi), merupakan pemeriksaan yang mudah dilakukan untuk menilai adanya disfungsi organ.

Penelitian terbaru yang dilakukan oleh Karlsson $\mathrm{dkk}^{25}$ di Swedia bertujuan untuk menilai apakah AST, ALT dan LDH dapat memprediksi terjadinya HIE pada bayi yang mengalami distres intrapartum. Dilakukan pemeriksaan AST, ALT, dan LDH dalam 12 jam setelah lahir. Dari hasil analisis pada 19 bayi yang mengalami HIE didapatkan bahwa nilai titik potong LDH $1049 \mathrm{U} / \mathrm{L}$ memiliki sensitivitas 100\% dan spesifitas $98 \%$ untuk memprediksi terjadinya HIE, ALT memiliki sensitivitas $95 \%$ dan spesifitas $90 \%$, sedangkan AST memiliki sensitivitas $85 \%$ dan spesifitas $98 \%$.

Sebagai kesimpulan pada bayi baru lahir dengan nilai Apgar menit kelima kurang dari 7 didapatkan insidens disfungsi hati 34\% dan tidak terbukti ada korelasi antara nilai Apgar menit kelima kurang dari 7 dengan kadar AST, ALT, bilirubin total, bilirubin indirek, bilirubin direk dan PT. Walaupun terdapat kecenderungan disfungsi hati pada bayi dengan nilai Apgar menit kelima kurang dari 7 , pemeriksaan uji fungsi hati mungkin tidak perlu dilakukan bila mendapatkan bayi hanya dengan kriteria nilai Apgar menit kelima kurang dari 7, karena tidak terbukti bermakna secara statistik. Perlu dilakukan penelitian lanjutan untuk melihat parameter uji fungsi hati dengan menggunakan kriteria asfiksia berdasarkan 
Ali K Alhadar dkk: Korelasi nilai APGAR menit kelima dengan kadar transaminase serum pada bayi baru lahir

AAP-ACOG atau dapat dibandingkan dengan keadaan HIE.

\section{Daftar pustaka}

1. Dzakpasu S, Joseph KS, Huang L, Allen A, Sauve R, Young D. Decreasing diagnoses of birth asphyxia in Canada: fact or artifact. Pediatrics 2009;123:668-72.

2. Low JA. Intrapartum fetal asphyxia:definition, diagnosis and classification. Am J Obstet Gynecol 1997;176:957-9.

3. Agarwal R, Jain A, Deorari AK, Paul VK. Postrescucitation management of asphyxiated neonates. Indian J Pediatr 2008;75:175-80.

4. Aurora S, Snyder EY. Perinatal asphyxia. Dalam: Cloherty JP, Eichenwald EC, Stark AR, penyunting. Manual of neonatal care. Edisi ke-5. Philadelphia: William \& Willkins; 2004.h.536-55.

5. Gomella TL. Perinatal asphyxia. Dalam: Gomella TL, Cunningham MD, Eyal FG, Zenk KE, penyunting. Neonatology management, procedures, on-call problems, diseases, and drugs. Edisi ke-5. Philadelphia: McGrawHill Companies; 2004.h.512-23.

6. Korst LM, Phelan JP, Wang YM, Martin GI, Ahn MO. Acute fetal asphyxia and permanent brain injury: a restrospective analysis of current indicators. J Matern Fetal Med 1999;8:101-6.

7. Hankins GD, Koen S, Gei AF, Lopez SM, Van Hook JW, Anderson GD. Neonatal organ system injury in acute birth asphyxia sufficient to result in neonatal encephalopathy. Obstet Gynecol 2002;99:688-91.

8. Ancel AM, Alix AG, Gaya F, Cabanas F, Burgueros M, Quero J. Multiple organ involvement in perinatal asphyxia. J Pediatr 1995;127:786-93.

9. Aminulah A. Konsekuensi kelainan sistemik berbagai organ tubuh akibat hipoksia dan iskemia neonatal. Dalam: Suradi R, Monintja HE, Amalia P, and Kusumowardhani D, Penyunting. Naskah lengkap Pendidikan Berkelanjutan Ilmu Kesehatan Anak FKUI XXXVIII. Penanganan mutakhir bayi prematur: memenuhi kebutuhan bayi prematur untuk menunjang peningkatan kualitas sumber daya manusia. Jakarta: Balai Penerbit FKUI; 1997.h.165-84.

10. Diehl-Jones WL, Askin DF. The neonatal liver part II: assessment and diagnosis of liver dysfunction. Neonatal Netw 2003;22:7-15.
11. Vaala WE. Peripartum asphyxia syndrome in foals. AAEP proceedings. 1999;45:247-53.

12. Tarcan A, Tiker F, Guvenir H, Gurakan B. Hepatic involvement in perinatal asphyxia. J Matern Fetal Med 2007;20:407-10.

13. Stoll BJ, Chapman IA. Hypoxia-ischemia. Dalam: Behrman RE, Kliegman RM, Jenson HB, Stanton BF, penyunting. Nelson textbook of pediatrics. Edisi ke-18. Philadelphia: Saunders; 2007.h.718-20.

14. Karlsson M, Blennow M, Nemeth A, Winbladh B. Dynamic of hepatic enzyme activity following birth asphyxia. Acta Paediatr 2006;95:1405-11.

15. Shah P, Riphagen S, Beyene J, Perlman M. Multiorgan dysfunction in infants with post-asphyxial hypoxicischemic encephalopathy. Arch Dis Child Fetal Neonatal Ed 2004;89:152-5.

16. Kew MC. Serum aminotransferase concentration as evidence of hepatocelular damage. Lancet 2000;355:591-2.

17. Godambe SV, Udani RH, Malik S, Kandalkar BM. Hepatic profile in asphyxia neonatorum. Indian J Pediatr 1997;34:927-30.

18. Bernstein D. The fetal to neonatal circulatory transition. Dalam: Behrman RE, Kliegman RM, Jenson HB, Stanton BF, penyunting. Nelson textbook of pediatrics. Edisi ke-18. Philadelphia: Saunders; 2007.h.1855-7.

19. Jacquemin E, Lykavieris P, Chaoui N, Hadchouel M, Bernard O. Transient neonatal cholestasis: origin and outcome. J Pediatr 1998;133:563-7.

20. Tiker F, Tarcan A, Kilicdag H, Gurakan B. Early onset conjugated hyperbilirubinmia in newborn infants. Indian J Pediatr 2006;73:409-12.

21. Rosenthal P. Assessing liver function and hypebilirubinemia in the newborn. Clin Chem 1997;43:228-34.

22. Thapa BR, Walia A. Liver function test and their interpretation. Indian J Pediatr 2007;74:663-71.

23. Batres LA, Maller ES. Laboratory assessment of liver function and injury in children. Dalam: Suchy FJ, Sokol RJ, Balistreri WF, penyunting. Liver disease in children. Edisi ke-2. Philadelphia: Lipincott Wiliams \& Wilkins; 2001.h.155-69.

24. Beshlawy A, Husein HA, Abouw-Elew, Kader MS. Study of protein C, protein $S$ and antithrombin III in hypoxic newborn. Pediatr Crit Care Med 2004;5:163-6.

25. Karlsson M, Wilberg-Itzel E, Chakkarapani E, Blennow M, Winbladh B, Thoresen M. Lactate dehydrogenase predicts hypoxic ischemic encephalopathy in newborn infants: a preliminary study. Acta Paediatr 2010;1:1-6. 